\title{
Efektivitas Pelatihan Komunikasi Interpersonal Terhadap Kepercayaan Diri Dan Harga Diri Pada Remaja Panti Asuhan
}

\author{
Kristiana Haryanti ${ }^{1}$, Eugenius Tintus Reynaldi ${ }^{2}$, Widawati Hapsari ${ }^{3}$, \\ Priscilla Lasty Fera ${ }^{4}$, Sunu Putri Pambajeng Wijiasih ${ }^{5}$
}

\author{
1,2,3 Staf Pengajar Fakultas Psikologi, Universitas Katolik Soegijapranata \\ ${ }^{4,5}$ Mahasiswa Program Pendidikan S-1 Psikologi, Fakultas Psikologi, Universitas \\ Katolik Soegijapranata
}

Korespondensi Penulis:

$\begin{array}{ll}\text { Nama } & : \text { Kristiana Haryanti } \\ \text { Alamat } & : \text { Fakultas Kedokteran Universitas Katolik Soegijapranata } \\ & \text { Jl. Pawiyatan Luhur Selatan IV No.1, Semarang, Jawa Tengah } \\ \text { Nomor Telepon } & :(024) 8441555,8505003 \\ \text { Email } & : \text { kristiana@ unika.ac.id }\end{array}$

\begin{abstract}
Abstrak
Latar Belakang Remaja yang tinggal di panti asuhan memiliki karakteristik yang berbeda dengan remaja yang tinggal bersama orang tuanya. Mereka mengalami banyak kendala fisik dan psikologis yang harus dihadapi. Situasi panti asuhan pasti memiliki suasana dan lingkungan yang berbeda dan hal ini membutuhkan perhatian, karena jika terjadi hambatan komunikasi maka akan berakibat pada kesulitan dalam menyesuaikan diri.
\end{abstract}

Tujuan Penelitian Dalam penelitian ini, peneliti memberikan pelatihan komunikasi interpersonal untuk melihat efektivitas pelatihan ini terhadap kepercayaan diri dan harga diri

Metode Metode penelitian ini menggunakan metode quasi eksperimen one group pretesr posttest design. Jumlah subyek dalam penelitian ini adalah 18 orang siswa SMK di Panti Asuhan X. Hipotesis penerlitian ini ada dua yaitu 1) ada pengaruh pelatihan komunikasi interpersonal terhadap kepercayaan diri dan 2) ada pengaruh pelatihan komunikasi interpersonal terhadap harga diri. Untuk menguji hipotesis dilakukan uji analisis Wilcoxson Signed Rank Test.

Hasil Hasil penelitian menunjukkan ada pengaruh pelatihan komunikasi interpersonal yang signifikan terhadap kepercayaan diri yang berarti pelatihan dari pelatihan ini terbukti efektif menngkatkan kepercayaan diri. Hasil jug amenunjukkan ada Pengaruh pelatihan komunikasi interpersonal yang signifikan terhadap harga diri. Artinya, pelatihan komunikasi interpersonal ini juga terbukti efektif meningkatkan harga diri. Penelitian ini juga melakukan evalasi pelatihan dan follow up action plan yang akan dilaporakan dalam diskusi hasil penelitian. 
Kesimpulan Berdasarkan hasil analisis yang telah dilakukan maka dapat disimpulkan bahwa pelatihan komunikasi interpersonal berpengaruh meningkatkan harga diri dan kepercayaan diri. Pelatihan komunikasi interpersonal ini terbukti efektif untuk menigkatkan kepercayaan diri dan harga diri pada remaja panti asuhan.

Kata kunci: pelatihan komunikasi interpersonal, kepercayaan diri, harga diri

\section{Pendahuluan}

Indonesia akan mengalami masa bonus demografi pada tahun 2030 hingga 2040. Artinya, pada rentang tahun tersebut jumlah penduduk produktif di Indonesia (15 hingga 64 tahun) akan lebih banyak dibandingkan penduduk yang tidak produktif (di bawah 15 tahun atau di atas 64 tahun). ${ }^{1 .}$ Apabila hal ini tidak dibarengi dengan pengembangan SDM di Indonesia, maka bonus demografi ini akan jadi hal yang sia-sia dan tidak dapat dimanfaatkan secara optimal untuk kemajuan Indonesia. Keuntungan demografi ini juga menjadi perhatian pemerintah Indonesia. Presiden Jokowi menegaskan bahwa untuk membangun SDM Indonesia salah satunya dapat dilakukan dengan meningkatkan kualitas pendidikan Sekolah Menengah Kejuruan. ${ }^{32}$.

Pemerintah pusat serius ingin memanfaatkan bonus demografi sebaik mungkin, dengan meningkatkan pendidikan. Sayangnya, peningkatan kualitas ini masih terbatas pada sektor formal saja, sementara sektor informal masih kurang mendapat perhatian. Akibatnya, yang fokus dikembangkan adalah hardskill, sementara softskill masih kurang mendapat perhatian. Padahal softskill juga merupakan bekal yang penting dalam dunia pekerjaan bagi para remaja yang telah menyelesaikan pendidikan SMKnya. Berbeda dengan hardskill yang dibutuhkan untuk mengerjakan sebuah pekerjaan, softskill dibutuhkan sebagai keterampilan yang mendukung seseorang untuk mengerjakan pekerjaannya. Salah satu softskill yang dibutuhkan dalam dunia kerja adalah komunikasi. Komunikasi sangat dibutuhkan karena tanpa adanya kemampuan komunikasi yang mumpuni, maka akan sulit untuk bekerja sama dengan orang lain.

Peneliti mewawancarai pengurus dari lima panti asuhan di Kota Semarang mengenai kelanjutan hidup dari anak-anak yang tinggal di panti asuhan. Kelima panti ini memiliki jawaban yang seragam: anak-anak yang sudah dianggap dapat berdiri sendiri akan dilepas dari panti untuk tinggal sendiri, namun tetap dipantau oleh pengurus panti. Karena panti asuhan memiliki keterbatasan dalam pembiayaan, maka panti asuhan akan mengupayakan agar anak-anak yang sudah berusia remaja masuk ke SMK (Sekolah Menengah Kejuruan) agar siap kerja lebih cepat. Hanya beberapa anak saja yang memang memiliki kecerdasan di atas rata-rata yang akan dibiayai sekolahnya hingga tingkat pendidikan tinggi.

Remaja yang tinggal bersama keluarganya berbeda dengan remaja yang tinggal di panti asuhan. Secara umum remaja memang memiliki kecenderungan untuk memberontak dari orang tuanya karena mulai muncul konformitas terhadap teman sebayanya. ${ }^{9}$ Remaja yang tinggal di panti tidak memiliki keluarga. Remaja yang tinggal di panti asuhan lebih banyak menerima pemenuhan kebutuhan-kebutuhan biologisnya 
ketimbang kebutuhan-kebutuhan non-biologisnya sebagai akibat dari terbatasnya jumlah pekerja sosial yang bekerja di panti asuhan. ${ }^{20}$.

Meskipun mayoritas remaja yang tinggal di panti asuhan sudah tinggal bersama dengan teman-temannya di panti, namun hal ini tidak otomatis membuat mereka saling terbuka antara satu dengan yang lainnya. Salah satu remaja penghuni panti asuhan menyatakan bahwa ia lebih memilih untuk memendam masalahnya daripada bercerita pada temannya. Salah satu alasannya adalah karena temannya seringkali tidak bersedia mendengarkan apabila ia bercerita sesuatu yang dianggap "tidak penting". Hal ini menunjukkan bahwa ada permasalahan yang terkait dengan komunikasi pada remaja yang tinggal di panti asuhan. Ada keengganan untuk bercerita karena remaja di panti asuhan masih belum bisa mendengarkan cerita dari temannya.

Rasa keengganan bercerita juga bisa disebabkan karena kurnag memiliki kepercayaan diri. Kepercayaan diri dapat diartikan sebagai sifat yakin dan percaya akan kemampuan yang dimiliki, sehingga tidak bergantung kepada orang lain serta mampu mengapresiasikan diri. Remaja yang memiliki kepercayaan diri akan mampu mengenali kekurangan dan kelebihan yang dimilikinya, mampu berpikir positif dan dapat secara mandiri mengembangkan potensi-potensi yang dimilikinya. ${ }^{28 .}$ Remaja yang tidak memiliki kepercayaan diri akan menunjukkan ciri-ciri yaitu memiliki pikiran negatif terhadap kemampuan yang dimiliki, menutup diri, konsep diri rendah, ${ }^{18}$ selalu berpikir buruk, tidak berani dalam mengambil keputusan secara mandiri dan takut mencoba halhal yang baru, serta takut mengungkapkan pendapatnya di depan umum. ${ }^{19}$.

Selain kepercayaan diri, remaja juga perlu memiliki harga diri. Harga diri (self esteem) merujuk pada sikap seseorang terhadap dirinya sendiri, mulai dari sangat negatif sampai sangat positif. ${ }^{6}$. Remaja yang memiliki harga diri tinggi akan dapat mengutarakan ide-ide dan pemikiran kreatifnya untuk memenuhi kebutuhan kognitifnya dan juga memiliki ciri-ciri yang terbuka dalam mengungkapkan pendapat. ${ }^{4}$ Ciri-ciri remaja yang memiliki harga diri yang tinggi menurut Henggaryadi, ${ }^{12}$ yaitu adanya kepercayaan diri yang tinggi, ambisius tetapi realistis terhadap kemampuannya, mandiri, kreatif, aktif dalam kegiatan-kegiatan fisik dan sosial, ekspresif, dan memiliki skor tinggi dalam intelegensi. Marwati, Prihartanti, dan Hertinjung juga menjelaskan bahwa ciri-ciri harga diri yang rendah juga ditemukan pada $46 \%$ remaja yang tinggal di panti asuhan. ${ }^{16}$. Ciri-ciri harga diri yang rendah yang ditunjukkan oleh remaja panti asuhan tersebut yaitu: remaja menganggap dirinya menjadi sumber masalah bagi lingkungan, tidak memiliki pendirian dan mudah menyerah, mengalami hambatan untuk mengekspresikan emosi negatif, terasing dari keluarga, kurang percaya diri, kurang aktif, mudah putus asa, dan mengalami kesulitan dalam proses sosialisasi. ${ }^{16,21 .}$

Dengan memahami kedua konsep (kepercayaan diri dan harga diri) ini maka kita dapat mengetahui bahwa ada ada kaitaan antara harga diri dan kepercayaan diri. Remaja yang memiliki harga diri dan kepercayaan diri ini akan mampu mengembangkan potensi-potensinya untuk menjadi agen perubahan untuk masa depan dan menyumbangkan pemikiran dan ide-ide kreatifnya sesuai dengan tuntutan perkembangan zaman. Hal tersebut tentu akan sulit terwujud apabila remaja memiliki permasalahan yang kompleks dalam masa perkembangannya seperti yang dialami oleh remaja di panti asuhan yang memiliki karakteristik pribadi yang berbeda dengan remaja yang tinggal di rumah orangtuanya. 
Apabila rasa tidak percaya diri dan harga diri rendah yang dimiliki oleh remaja panti asuhan tersebut tidak ditangani dengan baik maka dapat menyebabkan terhambatnya pengembangan potensi-potensi yang dimiliki remaja tersebut. Remaja yang tidak memiliki kepercayaan diri tidak akan mampu menilai potensi-potensi yang dimilikinya secara positif sehingga mengakibatkan potensi-potensi tersebut tidak dapat berkembang dengan baik. Hal serupa juga dialami oleh remaja yang memiliki harga diri yang rendah, yaitu bahwa remaja dengan harga diri yang rendah memiliki hambatan dalam pemenuhan kebutuhan aktualisasi dirinya yang sama dengan terhambatnya realisasi potensi-potensi yang dimilikinya.

Kepercayaan diri sendiri memiliki beberapa faktor yaitu komunikasi, ketegasan, dan penampilan diri. ${ }^{30}$ Gamble dan Gamble menjelaskan bahwa komunikasi yang melibatkan interaksi antara dua orang atau lebih disebut komunikasi interpersonal. ${ }^{10}$. Kemampuan komunikasi interpersonal yang dimiliki remaja sangat berpengaruh terhadap kepercayaan diri dalam diri remaja. Penelitian yang dilakukan oleh Sarinah dan Aziz membuktikan bahwa terdapat hubungan yang positif antara rasa percaya diri dan komunikasi interpersonal, semakin tinggi komunikasi interpersonal yang dilakukan oleh siswa kelas $\mathrm{X}$, maka rasa percaya diri siswa kelas $\mathrm{X}$ semakin tinggi. ${ }^{25}$. Hasil penelitian yang dilakukan oleh Dewanti, Yusmansyah, dan Widyastuti juga menyebutkan bahwa ada hubungan positif antara kepercayaan diri dalam berkomunikasi dengan komunikasi interpersonal. ${ }^{8}$.

Hasil wawancara di panti asuhan $\mathrm{X}$ juga mengungkap bahwa sebagian besar remaja yang tinggal di panti asuhan tersebut berasal dari Nias, dan sisanya berasal dari Kalimantan, Jawa, dan NTT. Para remaja tersebut hanya dirawat oleh dua orang tenaga pengelola. Tenaga pengelola yang terbatas ini mrnyebabkan perawatan dan perhatian terhadap anak-anak panti asuhan ini masih kurang maksimal.

Hasil observasi dan wawancara juga menunjukkan remaja yang berasal dari Nias yang merupakan mayoritas dari penghuni panti asuhan seringkali mengelompok tersendiri menggunakan bahasa daerah ketika mengobrol satu sama lain. Hal itu menyebabkan remaja lain yang berasal dari daerah minoritas seperti Jawa memilih untuk menghindar dari remaja Nias tersebut karena mereka tidak suka dan kurang berani menegur karena merasa sungkan. Hal itu menunjukkan adanya ciri harga diri rendah yang masih terdapat pada remaja panti tersebut yaitu adanya hambatan dalam mengekspresikan emosi negatif dan kemungkinan akan mengalami kesulitan dalam proses sosialisasi. ${ }^{16,21 .}$

Remaja yang berasal dari Nias yang mengelompok tersendiri dan menggunakan bahasa daerahnya ketika mengobrol satu dengan lainnya menunjukkan masih kurangnya keterbukaan dalam berkomunikasi dengan remaja panti yang lain. Remaja yang kurang terbuka dalam berkomunikasi berarti remaja tersebut belum memiliki komunikasi interpersonal yang efektif. ${ }^{7}$ Menurut Suaebah komunikasi interpersonal yang tidak efektif akan berdampak pada ketidakharmonisan dalam keluarga, yang juga berarti terdapat ketidakharmonisan di antara orang-orang di panti asuhan, sebab panti asuhan merupakan lembaga sebagai pengganti keluarga. ${ }^{27,17}$. Selain itu, peneliti juga menemukan ada beberapa remaja yang tidak berani mengungkapkan pendapatnya secara terbuka karena remaja tersebut memiliki keyakinan yang berbeda dengan remaja lainnya. Remaja yang kurang percaya diri menurut Monnalisza \& Neviyarni 
menunjukkan ciri-ciri masih bergantung pada orang lain dalam mengambil keputusan dan takut mengungkapkan pendapatnya di depan umum. ${ }^{19}$.

Berdasarkan hasil observasi dan interview yang dilakukan ditemukan permasalahan remaja di panti asuhan mengarah pada permasalahan tentang harga diri dan kepercayaan diri. Latar belakang teori menyatakan bahwa faktor-faktor yang berpengaruh terhadap harga diri dan kepercayaan diri adalah bagaimana seseorang dapat bekomunikasi secara interpersonal. Ini berarti bahwa ada kemungkinan kemampuan interpersonal yang baik akan dapat membuat seseorang lebih percaya diri dan memiliki harga diri. Oleh sebab itu, peneliti tertarik untuk menguji apakah Pelatihan Komunikasi Interpersonal efektif untuk meningkatkan kepercayaan diri dan harga diri? Penelitian ini bertujuan untuk menguji efektivitas pelatihan komunikasi Interpersonal terhadap kepercayaan diri dan harga diri pada remaja panti asuhan.

\section{Metode}

Penelitian ini menggunakan jenis penelitian quasi experiment the one-group pretest-posttest design. The one-group pretest-posttest design ini dilakukan dengan menilai respon peserta pelatihan dua kali yaitu sebelum (pretest) dan sesudah (posttest) pemberian intervensi atau perlakuan dengan cara yang sama persis. Respon peserta pelatihan setelah pemberian intervensi (posttest) ini kemudian dibandingkan dengan respon peserta sebelum pemberian intervensi (pretest) untuk mengetahui apakah ada perubahan seperti peningkatan atau penurunan, atau justru tidak ada perubahan sama sekali baik sebelum maupun setelah diberikan intervensi. ${ }^{29}$ Adapun desain experimennya adalah sebagai berikut:

Gambar 1. The One-Group Pretest-Posttest Design

$$
\mathrm{O} 1-\mathrm{X}-\mathrm{O} 2
$$

Keterangan :

Q1 : Pretest

a. Tes Kepercayaan Diri

b. Tes Harga Diri

X : Pelatihan Komunikasi Interpersonal

Q2 : Posttest
a. Tes Kepercayaan Diri
b. Tes Harga Diri
c. Angket Evaluasi Pelatihan 


\section{Subjek Penelitian}

Populasi merupakan sekelompok individu yang menarik perhatian peneliti untuk melakukan penelitian. ${ }^{15}$ Populasi dalam penelitian eksperimen ini adalah remaja perempuan panti asuhan yang berusaia $16-18$ tahun yang tinggal di panti asuhan $\mathrm{X}$ dan sedang menempuk pendidikan di SMK dan bersedia untuk mengikuti pelatihan komunikasi nterpersonal dari awal sampai akhir. Dari 23 orang yang tinggal di Panti Asuhan terdiri dari 22 perempuan dan 1 (satu) laki-laki. Hanya 18 orang perempuan yang bersedia mengikuti seluruh agenda pelatihan dan kesemuanya dijadikan subyek penelitian.

\section{Metode Pengumpulan Data}

Metode pengumpulan data dalam penelitian ini menggunakan alat ukur berupa skala kepercayaan diri dan skala harga diri yang disusun berdasarkan model skala Likert. Joshi, Kale, Chandel, dan Pal mengatakan bahwa skala Likert merupakan jenis skala untuk mengukur pendapat atau persepsi individu mengenai suatu variabel tertentu yang diimplementasikan dalam beberapa item/pernyataan. Skala kepercayaan diri dan harga diri dalam penelitian ini hanya memuat empat pilihan jawaban yaitu Sangat Tidak Sesuai (STS), Tidak Sesuai (TS), Sesuai (S), dan Sangat Sesuai (SS). ${ }^{14}$ Menurut Widoyoko skala Likert memiliki dua jenis item pernyataan di dalamnya yaitu item-item favorable (bersifat positif) dan item-item unfavorable (bersifat negatif). Item-item favorable dalam skala kepercayaan diri dan harga diri dimulai dari skor 1 sampai 4, sedangkan item-item unfavorable-nya dimulai dari skor 4 sampai $1 .{ }^{31}$

Skala kepercayaan diri pada penelitian ini terdiri dari 20 item yang disusun berdasarkan lima aspek kepercayaan diri yaitu keyakinan akan kemampuan diri, optimisme, objektif, bertanggung jawab, serta rasional. 20 item tersebut semuanya favorable. Peneliti melakukan uji coba skala kepercayaan diri terhadap 145 siswa di SMK X di Klaten. Hasil analisis validitas terhadap 20 item dalam skala kepercayaan diri menunjukkan bahwa sebanyak 12 item dinyatakan valid sedangkan 8 item dinyatakan gugur. Cronbach's Alpha skala kepercayaan diri adalah sebesar 0.841 . Angka 0.841 tersebut lebih besar dari 0.60 ( $\mathrm{r}>0.60$ ). Maka dengan demikian, skala kepercayaan diri dengan 12 item tersebut dinyatakan reliable.

Skala harga diri dalam penelitian ini yang terdiri dari tiga dimensi yaitu perasaan keberhargaan diri, perasaan efikasi diri, dan perasaan diri yang otentik diimplementasikan ke dalam 15 item pernyataan yang juga terdiri dari beberapa item favorable dan beberapa item unfavorable. Peneliti juga melakukan uji coba skala harga diri terhadap 200 siswa SMK X di Demak. Hasil analisis validitas terhadap 15 item skala harga diri didapati bahwa sebanyak 13 item dari skala tersebut dinyatakan valid sedangan 2 item lainnya dinyatakan gugur. Cronbach's Alpha skala harga diri adalah sebesar 0.744. Angka 0.744 tersebut lebih besar dari 0.60 ( $\mathrm{r}>0.60)$. Maka dengan demikian skala harga diri dengan 13 item tersebut dinyatakan reliable.

Modul pelatihan komunikasi interpersonal dalam penelitian ini disusun berdasarkan lima aspek komunikasi interpersonal yang efektif menurut DeVito yaitu 
aspek aspek keterbukaan, empati, sikap mendukung, sikap positif, dan kesetaraan. ${ }^{7}$ Judul yang diberikan peneliti untuk modul pelatihan komunikasi interpersonal ini yaitu "Speak Out". Modul pelatihan ini memiliki beberapa bagian yaitu bagian awal yang berisi konsep dasar komunikasi interpersonal, tujuan pelatihan, serta rancangan pelatihan. Bagian kedua yang merupakan sesi "Talk it out" yang menekankan aspek sikap mendukung dan sikap positif dengan penerapannya. Bagian terakhir yaitu sesi "Rasa Mu-Rasa Ku" yang mengandung aspek keterbukaan, empati, dan kesetaraan dalam komunikasi interpersonal dengan penerapannya. Sesi "Talk it out" dan sesi "Rasa $\mathrm{Mu}-\mathrm{Rasa} \mathrm{Ku}$ " tersebut masing-masing terdiri dari dua aktivitas yaitu "Aktivitas 1" dan "Aktivitas 2".

Jenis pengujian validitas modul pelatihan komunikasi interpersonal ini adalah validitas isi. Validitas isi merupakan validitas yang di estimasi lewat pengujian terhadap kelayakan atau relevansi isi modul melalui analisis rasional oleh panel yang berkompeten atau melalui expert judgment. Menurut Noah dan Ahmad, modul yang baik harus memiliki validitas isi. ${ }^{3}$. Hendryadi menambahkan bahwa uji validitas isi ini dilakukan oleh para pakar yang berkompeten melalui analisis rasional mereka (expert judgement). ${ }^{11}$. Para pakar yang berkompeten dalam memberikan penilaian pada modul ini terdiri dari enam orang dosen Fakultas Psikologi, Unika Soegijapranata.

\section{Hasil}

Analisis data dalam penelitian ini menggunakan analisis nonparametrik dengan teknik Wilcoxon Signed Rank Test pada SPSS. Hidayat dan Istiadah mengatakan bahwa Wilcoxon Signed Rank Test merupakan teknik untuk melakukan uji beda pada dua sampel yang berpasangan apakah kedua sampel tersebut memiliki rata-rata yang secara nyata berbeda atau tidak. ${ }^{13}$ Teknik Wilcoxon dalam penelitian ini bertujuan untuk menguji perbedaan data kepercayaan diri dan harga diri sebelum dan sesudah subjek mengikuti pelatihan komunikasi interpersonal. Hidayat dan Istiadah juga menjelaskan Wilcoxon juga dapat mencari perbedaan skor yang diperoleh antara keduanya yang kemudian disusun dalam suatu peringkat mulai dari skor terkecil hingga skor tertinggi (rank order). ${ }^{13}$

Hasil analisis menghasilkan nilai rata-rata data kepercayaan diri lebih tinggi sesudah mengikuti pelatihan komunikasi interpersonal $($ mean $=50.72)$ jika dibandingkan dengan sebelum mengikuti pelatihan (mean = 48.61). Ada 4 (empat) subjek memiliki kepercayaan diri yang masih rendah setelah diberi pelatihan komunikasi interpersonal (negative ranks). Sedangkan subjek yang memiliki kepercayaan diri yang tinggi setelah diberi pelatihan komunikasi interpersonal ada 13 orang (positive rank). Masih ada 1 (satu) orang yang sama sekali tidak mengalami perubahan kepercayaan diri setelah diberi pelatihan. Hasil analisis untuk menguji hypothesis pertama menunjukkan $\mathrm{z}=-2.980 ; \mathrm{p}=0.0015(\mathrm{p}<0.01)$, maka dapat dikatakan bahwa terdapat peningkatan yang sangat signifikan pada data kepercayaan diri subjek setelah mengikuti pelatihan komunikasi interpersonal. Berdasarkan hasil tersebut maka hipotesis dalam penelitian ini diterima yaitu bahwa ada pengaruh pelatihan komunikasi interpersonal terhadap peningkatan kepercayaan diri. Setelah mengikuti pelatihan komunikasi interpersonal kepercayan diri subjek lebih tinggi 
daripada sebelum mengikuti pelatihan komunikasi interpersonal. Oleh sebab itu hipotesis pertama dalam penelitian ini diterima. Pelatihan Komunikasi Interpersonal efektif dalam meningkatkan kepercayaan diri.

Selanjutnya untuk mengetahui apakah ada perbedaan yang signidikan disetiap aspek kepercayaan diri dapat dilihat di Tabel 1 berikut ini:

Tabel 1. Signifikansi Rata-rata Peningkatan Tiap Aspek Kepercayaan Diri

\section{Test Statistics $^{\mathbf{a}}$}

\begin{tabular}{lllll}
$\begin{array}{l}\text { Posttest }- \\
\text { PretestAspek }\end{array}$ & $\begin{array}{l}\text { Posttest }- \\
\text { PretestAspek } \\
\text { Optimis }\end{array}$ & $\begin{array}{l}\text { Posttest }- \\
\text { Pretest Aspek } \\
\text { Obyektif }\end{array}$ & $\begin{array}{l}\text { Posttest }- \text { Pretest } \\
\text { Aspek }\end{array}$ & $\begin{array}{l}\text { Posttest }- \\
\text { Pretest } \\
\text { Aspek } \\
\begin{array}{l}\text { Akan } \\
\text { Kemampuan }\end{array}\end{array}$ \\
& & & Bertanggung & Rasional \\
Diri & & Jawab & \\
$-1.667^{\mathrm{b}}$ & $-1.258^{\mathrm{b}}$ & $-.188^{\mathrm{c}}$ & $-2.138^{\mathrm{b}}$ & $-2.581^{\mathrm{b}}$ \\
.096 & .208 & .851 & .033 & .010 \\
\hline
\end{tabular}

a. Wilcoxon Signed Ranks Test

b. Based on negative ranks.

c. Based on positive ranks.

Berdasarkan table tersebut maka perbedaan yang terjadi pada aspek rasional adalah $\mathrm{z}=-2.581$ dengan $\mathrm{p}<0.05(\mathrm{p}=0.01,2$ tail; 1 tail $\mathrm{p}=0.005)$, yang berarti signifikan. Selanjutnya untuk aspek optimis $z=-1.258$ dengan $p>0.05(p=0.208,2$ tail; $\mathrm{p}=0.1041$ tail) yang berarti tidak signifikan. Analisis perbedaan untuk aspek bertanggung jawab menunjukkan hasil yang signifikan $\mathrm{z}=-2.138$ dengan $\mathrm{p}<0.05(\mathrm{p}=$ $0.033,2$ tail; $\mathrm{p}=0.0165,1$ tail). Perbedaan yang signifikan juga ditemukan pada aspek keyakinan terhadap kemampuan diri yang ditunjukkan dengan $\mathrm{z}=-1.667$ dengan $\mathrm{p}<$ 0.05 ( $\mathrm{p}=0.096,2$ tail; $\mathrm{p}=0.048,1$ tail). Terakhir, aspek obyektif dengan $\mathrm{z}=-0,188$ dengan $\mathrm{p}<0.05(\mathrm{p}=0.851,2$ tail; $\mathrm{p}=0.425,1$ tail) menunjukkan hasil yang tidak signifikan.

Analisis Wilcoxon juga dilakukan untuk menguji apakan ada peningkatan yang secara nyata berbeda/signifikan pada data harga diri kelompok subjek penelitian sesudah diberi intervensi pelatihan dibandingkan dengan sebelum diberi pelatihan. Hasil analisis dengan teknik Wilcoxon Signed Rank Test menghasilkan nilai rata-rata data harga diri setelah mengikuti pelatihan komunikasi interpersonal secara deskriptif lebih tinggi sesudah mengikuti pelatihan (39.28) dari sebelum mengikuti pelatihan (37.83). Subjek yang data harga dirinya lebih rendah sesudah diberi pelatihan komunikasi interpersonal (negative ranks) sebanyak 5 (lima) orang. Subjek yang data harga dirinya lebih tinggi sesudah diberi pelatihan komunikasi interpersonal (positive ranks) sebanyak 
9 (sembilan) orang. Subjek yang sama sekali tidak mengalami perubahan dalam data harga dirinya setelah diberi pelatihan komunikasi interpersonal (ties) sebanyak 4 (empat) orang. Hasil signifikansi nilai peningkatan harga diri yang terjadi setelah subjek mendapat pelatihan komunikasi interpersonal juga menunjukkan hasil yang signifffikan $\mathrm{Z}=-1.706, \mathrm{p}=0.044(\mathrm{p}<0.05)$. Berdasarkan hasil tersebut maka hipotesis dalam penelitian eksperimen ini diterima yaitu ada pengaruh pelatihan komunikasi interpersonal terhadap peningkatan harga diri. Setelah mengikuti pelatihan komunikasi interpersonal harga diri subjek lebih tinggi daripada sebelum mengikuti pelatihan komunikasi interpersonal.

Signifikansi rata-rata peningkatan setiap aspek harga diri subjek setelah mengikuti pelatihan komunikasi interpersonal didapatkan hasil sebagai berikut: perbedaan yang terjadi pada aspek perasaan keberhargaan diri adalah $\mathrm{z}=-0.749$ dengan $\mathrm{p}>0.05(\mathrm{p}=0.454,2$ tail; 1 tail $\mathrm{p}=0.227)$, yang berarti tidak signifikan. Selanjutnya untuk aspek perasaan efikasi diri $\mathrm{z}=-2.411$ dengan $\mathrm{p}>0.05(\mathrm{p}=0.016,2$ tail; $\mathrm{p}=$ $0.008,1$ tail) yang berarti signifikan. Hal itu berarti ada peningkatan yang secara nyata terjadi pada aspek perasaan efikasi diri setelah mengikuti pelatihan. Selanjutnya perbedaan yang terjadi pada aspek perasaan diri yang otentik diperoleh $\mathrm{z}=-0.516$ dengan $\mathrm{p}>0.05$ ( $\mathrm{p}=0.606,2$ tail; $\mathrm{p}=0.303,1$ tail) berarti tidak signifikan. Hal itu berarti tidak ada peningkatan yang secara nyata terjadi pada aspek perasaan diri yang otentik setelah mengikuti pelatihan.

\section{Hasil Follow Up Action Plan Pelatihan Komunikasi Interpersonal}

Hasil analisis data penelitian ini juga didukung oleh data hasil follow up yang diisi oleh seluruh subjek dalam penelitian ini setelah mereka melakukan rencana perilaku (action plan) yang mereka buat sendiri dalam kurun waktu satu bulan. Pada lembar action plan masing-masing subjek penelitian menuliskan jumlah rencana perilaku yang berbeda-beda menurut kesanggupan mereka masing-masing untuk melakukannya dalam kurun waktu satu bulan. Semua rencana perilaku yang dibuat oleh masing-masing subjek tersebut mengandung kelima aspek komunikasi interpersonal yang menurut DeVito yaitu aspek keterbukaan, empati, sikap mendukung, sikap positif, dan kesetaraan. ${ }^{7}$

Subjek penelitian yang telah melakukan rencana-rencana perilaku yang mereka buat sendiri dalam kurun waktu satu bulan tersebut kemudian dievaluasi keberhasilan penerapan rencana-rencana perilaku tersebut pada sesi follow up. Hasilnya menunjukkan sebagian besar subjek penelitian berhasil sepenuhnya melakukan rencanarencana perilaku yang mereka buat sendiri dalam kurun waktu satu bulan. Ditemukan satu subjek yang hanya dapat melakukan empat dari enam rencana perilaku yang dibuatnya dalam waktu satu bulan. Berdasarkan data keseluruhan hasil follow up subjek penelitian tersebut, rata-rata prosentase keberhasilan penerapan perilaku komunikasi interpersonal yang dicapai oleh seluruh subjek penelitian ini adalah 98\%. Sebanyak 17 subjek mencapai presentase keberhasilan sebesar $100 \%$ dan hanya terdapat satu subjek saja yang mencapai presentase keberhasilan $66,67 \%$. 


\section{Hasil Evaluasi Akhir Pelatihan Komunikasi Interpersonal}

Evaluasi akhir pelatihan menggunakan 17 item yang dikelompokkan dalam empat bagian yaitu isi pelatihan, fasilitas/sarana prasarana, fasilitator/pelatih, dan pelaksanaan pelatihan, serta kolom uraaian untuk mendapatkan tambahan usul/saran. Alternatif jawaban yang dapat diberikan adalah dari Sangat Tidak Memuaskan (STM) sampai dengan Sangat Memuaskan (SM) dengan skor 1 sampai dengan 10. Semakin mendekati angka 10 skor penilaian tiap item maka tingkat kepuasan dari pelatihan semakin tinggi. Sebaliknya, jika skor penilaian tiap item semakin mendekati angka 1, maka tingkat kepuasan dari pelatihan semakin rendah.

Berdasarkan perhitungan maka diperoleh rata-rata skor hasil evaluasi akhir pelatihan yaitu sebesar 8.1. Adapun rincian rata-rata skor hasil evaluasi akhir pelatihan secara berturut-turut: isi pelatihan sebesar 8.6, fasilitas/sarana prasarana 7.9, fasilitator/pelatih sebesar 8, dan pelaksanaan pelatihan sebesar 8.1. Rata-rata skor hasil evaluasi akhir pelatihan termasuk baik secara keseluruhan dan mendekati skor 10 sehingga dapat dikatakan subjek merasa puas mengikuti pelatihan komunikasi interpersonal.

\section{Diskusi}

Hasil analisis data yang telah dilakukan ditemukan bahwa hipotesis pertama dalam penelitian ini diterima, yaitu ada pengaruh pelatihan komunikasi interpersonal terhadap peningkatan kepercayaan diri. Setelah mengikuti pelatihan komunikasi interpersonal maka kepercayaan diri akan lebih tinggi jika dibandingkan sebelum mengikuti pelatihan komunikasi interpersonal. Hipotesis pertama dalam penelitian ini diterima maka pelatihan komunikasi interpersonal ini efektif untuk meningkatkan kepercayan diri. Hasil penelitian ini mendukung penelitian yang dilakukan oleh beberapa peneliti sebelumnya. Sarinah dan Aziz meneliti tentang hubungan rasa percaya diri dan komunikasi interpersonal dengan aktualisasi diri menyimpulkan bahwa terdapat hubungan yang positif antara rasa percaya diri dan komunikasi interpersonal. ${ }^{25}$ Penelitian yang dilakukan Dewanti, Yusmansyah, \& Widyastuti mengenai hubungan antara kepercayaan diri dalam berkomunikasi dengan komunikasi interpersonal juga menyimpulkan bahwa ada hubungan positif antara kepercayaan diri dalam berkomunikasi dengan komunikasi interpersonal. ${ }^{8}$ Penelitian lain yang dilakukan oleh Pratidina mengenai hubungan antara konsep diri dengan kemampuan komunikasi interpersonal pada remaja menyimpulkan adanya hubungan positif konsep diri dengan kemampuan komunikasi interpersonal. ${ }^{22}$.

Hasil analisis untuk hipotesis kedua dalam penelitian ini juga diterima. Ada pengaruh pelatihan komunikasi interpersonal terhadap harga diri. Setelah mengikuti pelatihan interpersonal maka harga diri akan lebih tinggi jika dibandingkan dengan sebelum mengikuti pelatihan komunikasi interpersonal. Hal ini juga berarti komunikasi interpersonal ini efektif untuk meningkatkan harga diri. Hasil penelitian ini juga sesuai dengan penelitian yang dilakukan sebelumnya oleh Bagaswuri dan Indrawati yang menemukan bahwa efektivitas komunikasi interpersonal memiliki hubungan positif yang signifikan dengan harga diri. ${ }^{5}$. Penelitian yang dilakukan oleh Purnomo dan 
Harmiyanto juga menemukan bahwa keterampilan komunikasi interpersonal berhubungan signifikan dengan kepercayaan diri pada. ${ }^{23}$ Penelitian lainnya yang mendukung yaitu penelitian yang dilakukan oleh Adiguna yang menyatakan bahwa keterbukaan diri dan harga diri memiliki hubungan positif yang sangat signifikan, dimana keterbukaan diri ini termasuk salah satu aspek dari komunikasi interpersonal. ${ }^{2}$ Savitri dan Hartati dalam penelitiannya juga membuktikan bahwa terdapat hubungan antara dukungan sosial dengan harga diri, dimana dukungan sosial yang dimaksud disini juga meliputi dukungan dalam komunikasi. ${ }^{26}$

Penelitian ini juga menunjukkan adanya perubahan perilaku pada subjek penelitian yang ditunjukkan dengan hasil follow up action plan yang menunjukkan hasil 98\%. Subjek penelitian mampu melaksanakan rencana kegiatannya sesuai dengan aspek-aspek yang dilatihkan. Hasil evaluasi akhir pelatihan juga menunjukkan bahwa rata-rata skor evaluasi adalah 8.1 (isi pelatihan, fasilitas/sarana prasarana, fasilitator/pelatih, dan pelaksanaan pelatihan) yang berarti peserta pelatihan termasuk puas dengan pelatihan komunikasi interpersonal yang diberikan.

\section{Kesimpulan}

Berdasarkan hasil analisis yang telah dilakukan maka dapat disimpulkan bahwa pelatihan komunikasi interpersonal berpengaruh untuk meningkatkan harga diri dan kepercayaan diri. Hal ini telah dibuktikan dengan meningkatnya harga diri dan kepercayaan diri setelah mengikuti pelatihan komunikasi interpersonal. Pelatihan komunikasi interpersonal ini terbukti efektif untuk menigkatkan kepercayaan diri dan harga diri pada remaja panti asuhan.

\section{Persetujuan Etik}

Penelitian ini telah mendapatkan persetujuan dari pimpinan Panti Asuhan dan responden yang terlibat dalam penelitian.

\section{Ucapan Terima Kasih}

Ucapan terima kasih kepada Universitas Katolik Soegijapranata yang telah memberikan dana penelitian sehingga artikel ini dapat diterbitkan 


\section{Daftar Pustaka}

1. Afandi, T. (2017, Mei 22). Bonus Demografi 2030-2040: Strategi Indonesia Terkait Ketenagakerjaan Dan Pendidikan. Jakarta, DKI Jakarta, Indonesia

2. Adiguna, N. A. (2016). Hubungan Antara Harga Diri Dan Keterbukaan Diri Pada Mahasiswa Perantauan. Universitas Katolik Soegijapranata Semarang. Diambil dari http://repository.unika.ac.id/id/eprint/13132

3. Ahmad, J., Amat, M. A. C., Yahaya, S. N., Yusof, R., \& Alias, S. R. (2011). The construction, validity, reliability and effectiveness of drug rehabilitation module on self concept female addicts and motivation achievement of male addicts in Malaysia. International Journal of Hummanities and Social Sciences, 1(10), p. 217-228

4. Anindyajati, M., \& Karima, C. M. (2004). Peran Harga Diri Terhadap Asertivitas Remaja Penyalahguna Narkoba (Penelitian Pada Remaja Penyalahguna Narkoba di Tempat-Tempat Rehabilitasi Penyalahguna Narkoba). Jurnal Psikologi, 2(1), 49-73. Diambil dari https://digilib.esaunggul.ac.id/public/UEU-Journal-4952-

MaharsiAnindyajati,CitraMelisaKarima.pdf

5. Bagaswuri, E. M., \& Indrawati, E. S. (2018). Hubungan Antara Efektivitas Komunikasi Interpersonal Dengan Harga Diri Siswa Kelas Xii Sman 1 Semarang. Empati, 7(2), 361-367. Diambil dari https://ejournal3.undip.ac.id/index.php/empati/article/viewFile/21708/20077

6. Baron, R. A., \& Bryne, D. (2004). Psikologi Sosial: Jilid 1. (W. C. Kristiaji \& R. Medya, Ed.) (10 ed.). Jakarta: Erlangga

7. DeVito, J. A. (2016). The interpersonal communication book. (K. Fleming, Ed.) (14 ed.). London: Pearson. Diambil dari http://93.174.95.29/main/2236000/de780f1dfecdb8e3149e6dcda0b0358d/DeVit o\%2C Joseph A. - The interpersonal communication book-Pearson $\% 282016 \% 29$.pdf

8. Dewanti, A. R., Yusmansyah, \& Widiastuti, R. (2014). Hubungan Antara Kepercayaan Diri Dalam Berkomunikasi Dengan Komunikasi Interpersonal. Jurnal Bimbingan Konseling (ALIBKIN); Vol 3. No 1

9. Feist, J., \& Feist, G. (2008). Theories of personality (7th edition). USA: McGraw-Hill

10. Gamble, T. K., \& Gamble, M. (2014). Interpersonal communication : building connections together. Thousand Oaks (Calif.): Sage. Diambil dari https://books.google.co.id/books?id=ecogAQAAQBAJ\&printsec=copyright\&re dir_esc $=\mathrm{y} \# \mathrm{v}=$ onepage $\& \mathrm{q} \& \mathrm{f}=$ false

11. Hendryadi, H. (2017). Validitas Isi: Tahap Awal Pengembangan Kuesioner. Jurnal Riset Manajemen dan Bisnis (JRMB) Fakultas Ekonomi UNIAT, 2(2), p. 169-178. https://doi.org/10.36226/jrmb.v2i2.47

12. Henggaryadi, G. (2012). Hubungan antara body image dengan harga diri pada remaja pria yang mengikuti latihan fitness/kebugaran. Jurnal Universitas Gunadarma, $00, \quad$ p. $1-23 . \quad$ Diambil dari https://oldsite.gunadarma.ac.id/library/articles/graduate/psychology/2009/Artikel 
_10504063.pdf

13. Hidayat, T., \& Istiadah, N. (2011). Panduan Lengkap Menguasai SPSS 19 untuk Mengolah Data Statistik Penelitian. (J. Setyaji, Ed.) (Cet. 1). Jakarta: MediaKita. Diambil dari https://books.google.co.id/books?id=j0KZjkxjRXMC\&printsec=frontcover\&hl= $\mathrm{id} \# \mathrm{v}=$ onepage $\& \mathrm{q} \& \mathrm{f}=$ false

14. Joshi, A., Kale, S., Chandel, S., \& Pal, D. (2015). Likert Scale: Explored and Explained. British Journal of Applied Science \& Technology, 7(4), p. 396-403. https://doi.org/10.9734/bjast/2015/14975

15. Marczyk, G. R., DeMatteo, D., \& Festinger, D. (2005). Essentials of Research Design and Methodology (Essentials of behavioral science series). (A. S. Kaufman \& N. L. Kaufman, Ed.) (1 ed.). Hoboken, N.J: John Wiley \& Sons Inc. Diambil dari http://93.174.95.29/main/57000/91f71317d0763cc57ccdbe5fa0869396/\%28Esse ntials of behavioral science series\%29 Geoffrey R. Marczyk\%2C David DeMatteo\%2C David Festinger - Essentials of Research Design and Methodology-John Wiley \%26 Sons \%282005\%29.pdf

16. Marwati, E., Prihartanti, N., \& Hertinjung, W. S. (2016). Pelatihan Berpikir Optimis Untuk Meningkatkan Harga Diri Pada Remaja Di Panti Asuhan. Indigenous: Jurnal Ilmiah Psikologi, 23. https://doi.org/10.23917/indigenous.v1i1.1790

17. Mazaya, K. N., \& Supradewi, R. (2011). Konsep diri dan kebermaknaan hidup pada remaja di panti asuhan. Proyeksi, 6(2), p. 103-112. https://doi.org/http://dx.doi.org/10.30659/p.6.2.103-112

18. Mirhan, J. B. K. J. (2016). Hubungan Antara Percaya Diri Dan Kerja Keras Dalam Olahraga Dan Keterampilan Hidup. Jurnal Olahraga Prestasi, 12(1), p. 86-96

19. Monnalisza, \& Neviyarni. (2018). Kepercayaan diri remaja panti asuhan Aisyiyah dan implikasinya terhadap layanan Bimbingan dan Konseling. Jurnal Penelitian Guru Indonesia, 3

20. Ningrum, N. (2012). Hubungan Antara Coping Strategy Dengan Kenakalan Pada Remaja Awal. Jurnal Psikologi Tabularasa, 7(1), p. 481-489. Diambil dari http://jurnal.unmer.ac.id/index.php/jpt/article/view/201/72

21. Pahlawani, N., \& Yuwono, S. (2010). Dinamika Psikologis Harga Diri Pada Waria. Indigenous, Jurnal Ilmiah Berkala Psikologi, 12(2), p. 161-168. https://doi.org/https://doi.org/10.23917/indigenous.v0i0.4755

22. Pratidina, G. (2015). Hubungan Antara Konsep Diri Dengan Kemampuan Komunikasi Interpersonal Pada Remaja. Skripsi. Semarang: Univesitas Diponegoro

23. Purnomo, D., \& Harmiyanto, H. (2016). Hubungan Keterampilan Komunikasi Interpersonal Dan Kepercayaan Diri Siswa Kelas X Sman 1 Garum Kabupaten Blitar. Jurnal Kajian Bimbingan dan Konseling, 1(2), 55-59. https://doi.org/10.17977/um001v1i22016p055

24. Sari, R. P., Rejeki, T., \& Mujab, A. (2006). Pengungkapan Diri Mahasiswa Tahun Pertama Universitas Diponegoro Ditinjau Dari Jenis Kelamin Dan Harga Diri. Jurnal Psikologi Universitas Diponegoro, 3(2), p. 11-25. https://doi.org/10.14710/jpu.3.2.11 - 25 
25. Sarinah, \& Aziz, A. (2010). Hubungan Komunikasi Interpersonal Dan Komitmn Terhadap Organisasi Dengan Kepuasan Kerja Karyawan Pt. Perkebunan Nusantara III (Persero). Jurnal Analitika, 2, p. 82-94

26. Savitri, V., \& Hartati, E. (2018). Hubungan Antara Dukungan Sosial dengan Harga Diri pada Tunanetra Dewasa Mantan Awas di Kota Semarang. Holistic $\begin{array}{lllll}\text { Nursing } \text { and Health } & \text { Science, } & \text { l(2), } & \text { p. } & 109 .\end{array}$ https://doi.org/10.14710/hnhs.1.2.2018.109-115

27. Suaebah, S. (2018). "Komunikasi Keluarga Harmonis" (Studi Kasus Komunikasi Interpersonal Keluarga Bapak Mugiyatno Dan Ibu Surati Juara Keluarga Harmonis Tingkat D.I.Y Tahun 2013). Universitas Muhammadiyah Yogyakarta. Diambil dari http://repository.umy.ac.id/bitstream/handle/123456789/22705/12\%29.NASKA H PUBLIKASI.pdf? sequence $=12$ \&isAllowed $=y$

28. Syam, A. (2017). Pengaruh Kepercayaan diri ( Self confidence) Berbasis Kaderisasi IMM Terhadap Prestasi Belajar Mahasiswa (Studi Kasus Di Program Studi Pendidikan Biologi Fakultas Keguruan Dan Ilmu Pengetahuan Universitas Muhammadiyah Pare-Pare ). Jurnal Biotek, 5, p. 87-102. http://journal.uinalauddin.ac.id/index.php/biotek/article/viewFile/3448/3243

29. Thyer, B. A. (2012). Pre-Experimental Research Designs. In QuasiExperimental Research Designs. p. 29-76. Oxford: Oxford Univ. Press. https://doi.org/10.1093/acprof:oso/9780195387384.003.0002

30. Utomo, D., \& Harmiyanto, H. (2016). Hubungan Keterampilan Komunikasi Interpersonal Dan Kepercayaan Diri Siswa Kelas X Sman 1 Garum Kabupaten Blitar. Jurnal Kajian Bimbingan Dan Konseling, 1(2), p. 55-59. https://doi.org/10.17977/um001v1i22016p055

31. Widoyoko, E. P. (2017). Evaluasi Program Pembelajaran (S. Z. Atijah (ed.); edisi ketujuh). Pustaka Pelajar

32. Wulandari, F. (2019, Juli 15). Pembangunan SDM, Jokowi: Ini Kunci Indonesia Ke Depan. Retrieved Oktober 3, 2019, from Tribunnews: https://www.tribunnews.com/pilpres-2019/2019/07/15/pembangunan-sdmjokowi-ini-kunci-indonesia-ke-depan

33. Zvolensky, M. J., Bonn-Miller, M. O., Feldner, M. T., Leen-Feldner, E., McLeish, A. C., \& Gregor, K. (2006). Anxiety sensitivity: Concurrent associations with negative affect smoking motives and abstinence selfconfidence among young adult smokers. Addictive Behaviors, 31(3), p. 429-439. https://doi.org/10.1016/j.addbeh.2005.05.027 